http://dx.doi.org/10.12775/szhf.2013.058

\title{
Maciej Zaremba Bielawski, Higieniści. Z dziejów eugeniki, Wydawnictwo Czarne, Wołowiec 2011, ss. 424.
}

W 2011 roku nakładem Wydawnictwa Czarne w Wołowcu ukazała się książka poświęcona dziejom eugeniki. Chodzi tutaj oczywiście o pozycję Higieniści. Z dziejów eugeniki Macieja Zaremby Bielawskiego. Jest to kolejna próba przybliżenia czytelnikom w Polsce „osiągnięć” eugeniki, zarówno europejskiej, jak i amerykańskiej, czy też wschodniej. Wydawnictwa polskie oferują dzisiaj opracowania najnowszych osiągnięć w wymienionej dziedzinie. Oczywiście można od razu dokonać ich podziału na personalistyczne i utylitarystyczne. Pierwsze będą stanowczo obstawać przy koncepcji życia jako daru, drugie - przy koncepcji autonomicznego człowieka, świadomego, mogącego podejmować decyzje o własnym życiu i śmierci. Do pierwszej kategorii można zaliczyć wydaną w 2012 roku pozycję Artura Jerzego Katolo Eugenika i eutanazja. Doświadczenia hitlerowskie, do drugiej natomiast - Etykę praktycznq Petera Singera. W ten sposób polski odbiorca wszechstronnych myśli z zakresu bioetyki ma przed sobą nie lada dylemat. Stoi przed trudnym wyborem jednej z wymienionych opcji w trakcie zakupu w księgarni. Większość publikacji z zakresu tematyki eugenicznej koncentruje się na odpowiadaniu na argumenty drugiej strony. Do tej pory nie powstała żadna, która by zakreśliła chociażby w skromnym wymiarze historię eugeniki, zwłaszcza w krajach skandynawskich, które do tej pory były skutecznie pomijane. Po drugie, często utrudnia się zrozumienie problematyki bioetycznej, podejmowanej przez najnowszych myślicieli. A ci, robiąc to mniej lub bardziej świadomie, odwołują się do fundamentalnych zagadnień z zakresu bioetyki, w tym oczywiście eugeniki. Choćby ze względu na próbę przełamania stagnacji, stereotypowego podejmowania się wyjaśnienia tematyki eugenicznej, nie sposób przecenić publikacji poruszającej właśnie tę problematykę - Higienistów Macieja Zaremby Bielawskiego. 
Obszerna, ponad czterystustronicowa publikacja, została poświęcona praktycznie jednej kwestii: rozwojowi praktyk eugenicznych w różnych obszarach językowych, w tym oczywiście niemieckiemu, szwedzkiemu, japońskiemu, czy amerykańskiemu oraz wzajemnemu przenikaniu się ich w latach dwudziestych - trzydziestych XX wieku. Zagadnienia podjęte przez autora książki dzielą się wyraźnie na cztery bloki tematyczne. Pierwsza część dotyczy historii praktyk eugenicznych, w ogóle - historii eugeniki, druga z kolei poświęcona jest krytyce higieny rasy oraz „szpitalowi przemienienia”, czy też ekologii higieny rasy, trzecia zaś - eugenice nad Wisłą i eugenice sarmackiej. Ostatnia część to refleksja na temat „niepełnowartościowego życia” i zagłady, jako równi pochyłej w historii zarówno krajów niemieckojęzycznych, jak i innych, będących pod ich wpływem.

Jesteśmy przyzwyczajeni do doszukiwania się w praktykach eugenicznych tego specyficznego zła, które łączy się bezpośrednio z obozami zagłady, powszechną sterylizacją "niepełnowartościowych” i "nieprzydatnych społecznie" jednostek, a już stąd niedaleko jest do ideologii Adolfa Hitlera i nazistowskich Niemiec. Zapomina się jednak o innych krajach europejskich, gdzie myśl eugeniczna była żywo podejmowana, gdzie wprowadzano masowe sterylizacje ludności (przykładem może być Szwecja, Norwegia). Klasyczne rozumienie terminu „eugenika” wraz z rozpowszechnianiem się idei darwinowskich, a wcześniej spencerowskich, było traktowane na równi $\mathrm{z}$ "higieną rasową". To pojęcie wielokrotnie wykorzystywano w historii dla rozumienia eugeniki jako dziedziny nauki, której zadaniem była walka o zapewnienie jak najlepszej sytuacji społecznej. Chodziło, innymi słowy, o budowanie społeczeństwa idealnego, właściwie zgodnego już z platońską koncepcją państwa. Ta myśl później została rozwinięta i uwzględniała mnóstwo czynników akcydentalnych, związanych bezpośrednio z rozwojem techniki, technologii, nauk ścisłych - w ogóle z intensywnym procesem rozwoju w imię nauki.

W pierwszej części publikacji Macieja Zaremby Bielawskiego odnaleźć można rekonstrukcję myśli eugenicznej wybitnych jej zwolenników począwszy od około lat dwudziestych XX wieku, którzy w przyszłości - najróżniejszymi drogami - wpłynęli zarówno na koncepcję nazistowską, jak i - w dalszej kolejności - naszych rodzimych myślicieli (ten ostatni wpływ rekonstruuje autor dosyć pobieżnie, prawdopodobnie z powodu braku dokładniejszych źródeł). I tak kolejne rozdziały poświęcone są takim kwestiom, jak: sterylizowanym kobietom, „pośledniemu materiałowi ludzkiemu”, „historii Wielkiej Paniki - koncepcji Spencera i Darwina oraz ich wpływom na myśl 
eugeniczną, problematyce eugenicznej w Anglii, Niemczech, Japonii, Francji, Włoszech i Ameryce Łacińskiej.

W drugiej części publikacji można odnaleźć materiały dotyczące wczesnej krytyki higieny rasy, a w szczególności krytyki Alvy Myrdal i Gilberta Chestertona. Ważną częścią jest oczywiście O milczeniu szwedzkiego wymiaru sprawiedliwości, gdzie autor próbuje odpowiedzieć na pytanie: dlaczego tak długo trwało milczenie o przymusowej sterylizacji kobiet w Szwecji? Kolejną kwestią jest przedstawienie wkładu Lutra i Kalwina do higieny rasy oraz ekologia higieny rasy. W trzeciej części Higienistów można zaznajomić się z paradoksami eugeniki nad Wisłą oraz z eugeniką sarmacką. Czwarta część jest poświęcona problemowi, który można postawić w formie pytania: Dlaczego demokratyczne Niemcy nie uznają ofiar higieny rasy za ofiary nazizmu? Istotny jest epilog zawarty w publikacji: „Życie niepetnowartościowe”. Pokusy, nadzieje i koszmary eugeniki sprywatyzowanej. Maciej Zaremba Bielawski wyjaśnia w nim, dlaczego książka powstała i jakie powinno być jej fundamentalne zadanie. Chodzi tutaj oczywiście o to, by „nie poszedł w niepamięć los Mathildy, Barbary, Idy i innych ofiar czystek, które w Szwecji i w innych krajach uprawiano pod hasłem higieny rasy”. Drugim powodem, równie istotnym, było wygranie procesu przeciw dwóm amerykańskim przedsiębiorstwom przez dziesięcioletnią Shaune Tamar Curlender. Dziewczyna przyszła na świat przez niedopatrzenie tych firm, w wyniku czego należy się zarówno jej, jak i jej rodzicom odszkodowanie.

Omówione w publikacji Macieja Zaremby Bielawskiego inspiracje eugeniczne przynależące nie tylko do nazizmu, ujawniają zarazem zmiany, jakie zachodziły w różnych krajach na świecie przed panowaniem w Europie hitlerowskich Niemiec. Książka Higieniści wprowadza czytelnika polskiego w przerażający świat praktyk sterylizacyjnych, dokonywanych nie tylko na kobietach, które prowadziły bezpośrednio do powstania zjawiska określanego mianem „higieny rasowej”. W książce mamy do czynienia z perspektywą obiektywną. Autor koncentruje swoją uwagę raczej na przedstawianiu fundamentalnych faktów $\mathrm{z}$ historii niż na negatywnym komentarzu. Musi on być pejoratywny, ponieważ takich działań, w imię dobra społecznego, czy też inaczej - dobra publicznego, do innych zaliczyć nie można. 